\title{
Minority Rights and Hindu Nationalism in India
}

\author{
Peter van der Veer* \\ Max Planck Institute for the Study of Religious and Ethnic Diversity, Gottingen \\ *Corresponding author. E-mail: vanderveer@mmg.mpg.de
}

\begin{abstract}
In this paper, I want to focus on some aspects of the political process in India that have an impact on the treatment of religious minorities. Much of the discussion on multicultural jurisdictions deals with differentiated citizenship rights that allow religious groups to maintain their normative universe. This literature shows the tensions surrounding individual and group rights. I want to approach the question of religious freedom from a rather different angle. I want to first focus on the protection of bare life in the face of religious violence and then examine the issue of conversion from one religion to another. The issues of human security and conversion are linked in India, since Hindu nationalists see Muslims as forcibly converted Hindus who should be reconverted. To highlight the importance of majoritarian nationalism rather than political systems in the treatment of religious minorities, I offer a brief comparison with China.
\end{abstract}

Keywords: minority; nationalism; Hindus; Muslims; violence

\section{Introduction}

The sovereign nation-state has to be the guarantor of religious freedom in the modern period. Multilateral treaties and international organizations may put pressure on nation-states and, in extreme cases, may even intervene, but the nation-state remains the ultimate arbiter of religious freedom. In many societies, the state faces the difficulty that it has to accommodate different religious groups, but at the same time has to unify the people into a nation. These two aims of the nation-state can be contradictory. This predicament is made worse by the politics of numbers in modern electoral democracies in which religious groups tend to be reconfigured as majorities and minorities. Liberal political theory argues that secularism is necessary for treating religions equally and neutrally, even to the extent that religion is thought to be a threat to democratic deliberation. ${ }^{1}$ When one allows freedom of religious expression under a secular Constitution, religion could and, more often than not, will play an important role in mobilizing and sometimes antagonizing people in the democratic process. ${ }^{2}$ However, it would be wrong to see electoral democracy as the single cause of communal trouble, since also in communist regimes, like those of China and Vietnam, where we do not have electoral democracies, the aim of national unity complicates the aim of accommodation of religious diversity.

Since the nation-state and nationalism are crucial in religious and political practice everywhere, it is clear that what the philosopher Charles Taylor calls "the Secular Age" extends beyond the West. ${ }^{3}$ The point that he makes is that the secular frames the

\footnotetext{
${ }^{1}$ Rawls (1971); Motzkin \& Fischer (2008).

${ }^{2}$ Brass (2003).

${ }^{3}$ Taylor (2007); see also Bilgrami (2016).
}

(c) The Author(s), 2021. Published by Cambridge University Press on behalf of KoGuan Law School, Shanghai Jiao Tong University. This is an Open Access article, distributed under the terms of the Creative Commons Attribution licence (http:// creativecommons.org/licenses/by/4.0/), which permits unrestricted re-use, distribution, and reproduction in any medium, provided the original work is properly cited. 
religious everywhere in modern societies that have the nation form. Asia is not an exception. Let me emphasize in passing that this does not mean that there is secularization everywhere in the sense of a decline in religious beliefs and practices. This is in fact also not the case in Western Christendom, where secularization is uneven and with different periodization. However, in many societies outside of Western Christendom, it is hardly possible to ascertain a decline or increase in religious beliefs and practices, since their religious traditions are not organized in the form of churches and thus one cannot count church membership or church attendance. In principle, Asian Christians could be counted, but the political situation often prevents one from doing it. Quantifications and extrapolations of the increase in the number of Protestants in China, predicting that China will become to the biggest Christian country in the world, are based on shaky statistics and may have dangerous implications, since they seem to be a rationale for more communist repression. ${ }^{4}$ Some urban environments, like those of Singapore or Shanghai, at first sight, look very secularized, because public manifestations of religion have been repressed or marginalized, but, if one looks a bit deeper, one finds a very lively religious life. ${ }^{5}$

Charles Taylor has argued that the rise in the nation-state and the mobilization around a national identity have been crucial for developing secular modernity. He proposes that a national society becomes "reflexive," by analogy with the reflexive individual, in taking a critical stance towards itself and devising ways of transforming it. ${ }^{6}$ According to Taylor:

we become modern by breaking out of "superstition." The enchanted world was one in which spirits and forces played a big role. The enchanted world was one in which these forces could cross a porous boundary and shape our lives, psychic and physical.

In Taylor's view, we are now "buffered" selves, not porous selves anymore. This line of reasoning obviously follows from Max Weber's notion of Entzauberung (disenchantment). ${ }^{7}$ In my view, Weber, Taylor, and a whole tradition of contemporary political thinkers (including Rawls and Habermas) miss the magic of nationalism and the modern nationstate, which Zygmunt Bauman captured much better.8 Not long after Weber died, Germany saw the rise of an ultra-nationalist movement that did anything but disenchant society. One of its striking aspects was a mobilization of society to grasp state power. After capturing the state, it effected a thorough rationalization of its bureaucratic apparatus in order to execute commands in a state hierarchy that had synthesized state institutions and party organization. There is nothing entzaubert (disenchanted) about this. It is precisely nationalism and state power that are magical, and it is difficult to escape their reach.

Nationalism uses founding myths, ritual and symbolic politics, exorcism, and unpredictable behaviour of charismatic leadership (all also elements of religion) in its mobilization of the people. Nationalism crosses the divide between democracies and communist regimes, between, say, Thailand, India, and Sri Lanka on the one hand and Vietnam and China on the other. The magic of the nation-state is often interpreted as populism, and thus as a special phenomenon in democracies, but, by definition, the nation-state rests on the idea that the people legitimizes the state. The crucial question posed and answered in nationalism is who belongs to "the people" and, more importantly, who does not belong and, further, what the relation is between minorities and majorities that are ethnically and or religiously defined. The production of majorities and the treatment of minorities as well as communal

\footnotetext{
${ }^{4}$ See e.g. the sociologist Fenggang Yang's predictions in April 2014 in Phillips (2014). See my critique of such use of statistics in sociology in Van der Veer (2016).

${ }^{5}$ Van der Veer (2015).

${ }^{6}$ Taylor (2016).

${ }^{7}$ Weber (1975), pp. 139, 155.

${ }^{8}$ Bauman (1989).
} 
violence seem to me the crucial questions in the study of secularism and religious freedom, but some of the recent literature inspired by Taylor's work ignores them. ${ }^{9}$

In this contribution, I want to focus on some aspects of the political process in India that have an impact on the rights of religious minorities. Much of the discussion on multicultural jurisdictions deals with differentiated citizenship rights that allow religious groups to maintain their normative universe. ${ }^{10}$ This literature shows the tensions surrounding individual and group rights, and the discussion often focuses on women's rights in traditional religious groups. ${ }^{11}$ In India, the most controversial judicial and political case has been that of Shah Bano, in which in 1985 the Supreme Court decided that, after divorce, the Muslim ex-husband had to pay alimony to his former wife. Afterwards, under pressure from Muslim groups that argued that the decision was against Muslim law, the Congress government enacted a law shifting the onus of maintaining her to her relatives or the Wakf Board (Board of Muslim Endowments). Hindu nationalists who argued that this was a politics of "appeasement" of the Muslim minority politically challenged this. ${ }^{12}$ However, here, I want to approach the question of religious freedom and minority rights from a rather different angle. I want to first focus on the protection of life in the face of religious violence, and then examine the issue of conversion from one religion to another. Finally, I want to examine some aspects of political processes in India and China that involve minority rights and religious freedom. The brief comparison with china is helpful. It shows that a secular democracy like India is not a better protector of religious minorities than a non-democratic regime like China. They are equally bad but, whereas in India, much of the violence is in communal riots, in China, there is state violence against religious minorities. In both societies, we see the repression of religious minorities, especially Muslims and Christians, combined with the promotion of majority religions. The argument here is that the relation between civilizational majorities and minorities in nationalism is more important than the difference between democratic and non-democratic polities.

\section{Hindu religious Nationalism}

India is generally seen as a secular state, although the Constitution does not proclaim it as such. The landmark assessment of the secularism of the Indian state is D. E. Smith's India as a Secular State. ${ }^{13}$ He distinguishes three distinct but interrelated sets of relationships concerning the state, religion, and the individual. The three sets of relations are: (1) religion and the individual (freedom of religion); (2) the state and the individual (citizenship); (3) the state and religion (separation of state and religion). Here, we are only concerned with number (1). Article 25(1) of the Indian Constitution deals with individual freedom of religion: "Subject to public order, morality and health and to the other provisions of this part, all persons are equally entitled to freedom of conscience and the right freely to profess, practice and propagate religion."

In an elaborate comment on Smith's book, Marc Galanter observes that Smith understands freedom of religion not as freedom of religion as it is in India, but freedom of religion as it ought to be ${ }^{14}$ He rightly points out that the Constitution and even more so the analysis of Donald Smith show the spirit of Hindu reformism and the essential interventional mission of the modern developmental state. The secular state intervenes in

\footnotetext{
${ }^{9}$ Künkler, Madeley, \& Shankar (2018).

${ }^{10}$ Kymlicka (1996); Shachar (2001).

${ }^{11}$ A recent example is the legal and political dispute about the right of women to enter the Sabarimala temple in Kerala; see The Economic Times (2018).

${ }^{12}$ Noorani (2004).

13 Smith (1963).

${ }^{14}$ Galanter (1998), p. 258.
} 
religious practice (e.g. by prohibiting the practice of untouchability). As Galanter succinctly puts it: "Secularism cannot be entirely neutral among religions when it undertakes to confine them to their proper sphere." 15 "Proper sphere" is of course what, according to the theory of modernization, would be the result of a process of secularization. This was certainly what important nationalists such as Jawaharlal Nehru (and even Muhammad Jinnah) hoped for but, while there is "secularism" in India, whatever that means, there is hardly secularization. There are attempts by Nehru and others to see India as a civilization and to see tolerance as a typical quality of that civilization. However, in fact, there is not a unified civilization, but a wide variety of Hindu and Muslim traditions within what is now known as India. Communities are not in themselves tolerant of each other, but attempt to be self-regulating while perceiving others in the spirit of hierarchical relativism. This was possible before the colonial period, and not anymore. Religious communities have come under the sway of colonial regulations and anti-colonial nationalism. Through the imperial encounter, Hinduism has been made into a majority religion by nationalism and, as a public religion, it cannot easily be relegated to the private sphere of individual belief.

A pertinent question asked by the political theorist Partha Chatterjee in this context is the following: Is secularism an adequate, or even appropriate, ground on which to meet the political challenge of Hindu majoritarianism $?^{16}$ It is indeed striking that the Hindu nationalists of the Bharatiya Janata Party (BJP), the ruling party in India today, have not attacked the secular state. Instead, they have argued that their rivals of the Congress Party are "pseudo-secularists," interested only in minority appeasement, thereby suggesting that they themselves are the genuine secularists. ${ }^{17}$ How does one square that suggestion with the undeniable fact that the current prime minister of India (then the chief minister of Gujarat) condoned (and allegedly orchestrated) a pogrom on Muslims in Gujarat in 2002? The answer to that question lies in the fact that the institutions of the secular state (police, judiciary) can be used to marginalize and even victimize a religious minority. Secularism in itself is not adequate in protecting the Muslim community in India.

At its core, the protection of religious freedom depends, first and foremost, on the protection of Muslim and Christian lives and property by the state. However, this has to be squared with the origin of the Indian secular state. It lies in a civil war between Hindus and Muslim that led to the partition of India and Pakistan and caused the displacement of around 14 million people and the loss of hundreds of thousands of lives. The traumatic series of events from which Pakistan and India emerged continues to bedevil the relations between Pakistan and India as well as between Hindus and Muslims in these countries. A number of wars followed the partition, the most important of which was the 1971 war in which Bangladesh seceded from Pakistan. In India, a system of riots has emerged especially around elections, mostly targeting Muslims, but still there had always been a measure of state protection for the Muslim and Christian minorities. ${ }^{18}$

This was, more or less, the situation until the early 1980s under mostly Congress Partyled central governments. However, since the 1980s, Hindu nationalists, using religious symbolism to mobilize people for anti-Muslim issues, have changed the political game in India drastically. In 1984, I was present at the start of a campaign "to liberate Ram's birthplace" in Ayodhya. The mosque that was allegedly built on the destroyed birthplace of Ram by the first Mughal Emperor Babar had already been contested since 1949 when miraculously an image of Ram had appeared inside the mosque. Given the devastating conflicts and population movements surrounding the partition, Nehru's government decided to deny both Hindu and Muslim communities access to the mosque except for one day

\footnotetext{
${ }^{15}$ Ibid., p. 259.

${ }^{16}$ Chatterjee (1998).

${ }^{17}$ Bhatt (2006), p. 134.

${ }^{18}$ Brass, supra note 2.
} 
annually when a Hindu committee was allowed to enter the mosque to worship the deity commemorating the day of his appearance. ${ }^{19}$ This was still the case in 1984 and has continued to be the case until the destruction of the mosque by Hindu nationalists (the Rasthriya Swayamsevak Sangh (RSS or National Volunteers' Organization), Vishwa Hindu Parishad (VHP), and BJP) in 1992. This campaign has not yet resulted in getting a temple built on the ruins of Babar mosque but it has certainly succeeded in transforming the BJP into a national party that was able to defeat the Congress in a series of elections until today. For a long time, the issue continued to be in the judicial process despite the BJP's political dominance. Only after the landslide victory of the BJP in the national elections of 2019, the Supreme Court of India gave its verdict that the Government of India was allowed to build a temple for the God Rama on the ruins of the mosque. ${ }^{20}$

If we think that what happens in India today under the Modi government as a "crisis of democracy," we have to realize that, rather than being a "crisis," it is the product of democracy, in which majoritarian nationalism is a driving force. The BJP has been democratically successful because of its instigation of violence. Showing yourself to be a strong leader by killing scores of people is not an uncommon strategy for electoral success. In Uttar Pradesh, a state with around 220 million inhabitants (if it would be a separate country, it would be the fifth country by population before Brazil or Pakistan), where Ayodhya is located, the BJP has also been victorious. Yogi Adityanath, the abbot of the Gorakhnath Math in Gorakhpur, and the disciple and successor of Abbot Avaidyanath, whom I came to know as a firebrand in the Ayodhya agitations, is now the chief minister. Politics in Uttar Pradesh, as in many other states in India, turn upon caste (Brahmans, Thakurs, Yadavs, and Dalits) and religion (Hindu-Muslim). The coalitions are constantly shifting. Hindu nationalism may be the element in Indian politics that has brought the BJP to power, but it would be a mistake to believe that the Congress Party did not use it. It would also be a mistake to think that only the innovative use of religious symbolism has brought the BJP to power, since politics is a constellation of conjectural forces, including importantly the decline of the "Congress System of patronage." 21 However, religious symbolism did play a major role in mobilizing people for a pro-Hindu/anti-Muslim cause, which also galvanized electoral politics. ${ }^{22}$

Obviously, nationalism (like religion) acquires some of its hegemonic force by claiming that it only "awakens" or "revitalizes" what is always already present, namely a unified nation. It constantly fights against both its internal and external enemies, as well as against processes of fragmentation. Region, language, history, caste, class, as well as religion can all be used both to unify and to diversify. Their alignments are conjectural and are sometimes produced by political strategy, as in the case of the Mandal (caste reservations) versus Mandir (Temple) opposition in 1990. In fact, in 1984 itself, not much attention was given to the campaign to liberate Ram's birthplace. More important was the assassination of Indira Gandhi by her Sikh bodyguards (now widely regarded as martyrs by the Sikh community) and the widespread attacks on Sikhs that followed it. ${ }^{23}$ Today, Sikh separatism does not get headlines, but it is useful to remind oneself of the jigsaw movement of nationalism in India with one religious nationalism following the other.

The dominance of the BJP in recent elections in India, especially shown by the landslide victory in the national elections of 2019 , has fostered the idea that secularism in India has declined and religious nationalism increased. This is partly, but not entirely, the case. It might be useful to consider that the Congress Party for the longest time has been able

\footnotetext{
${ }^{19}$ Van der Veer (1988).

${ }^{20}$ Ayodhya Judgment Supreme Court of India (2019), M Siddiq (D) Thr Lrs v. Mahant Suresh Das \& Ors, https:// www.sci.gov.in/pdf/JUD_2.pdf (access 10 November 2020).

${ }^{21}$ Kohli (1990).

${ }^{22}$ Van der Veer (1994).

${ }^{23}$ Das (1985).
} 
to keep many factions and directions, including religious nationalist forces, contained within itself. Mahatma Gandhi himself, despite his strong spiritual views, could be called a Hindu secular nationalist. Nevertheless, his broad understanding of nationalism resulted in his eventual assassination by Hindu nationalists who had a strong anti-Muslim sentiment and therefore rejected Gandhi's attempts to create religious unity. The BJP has always seen the secularism of the Congress Party as "pseudo-secular" in its "pampering" of the minorities and portrayed itself as truly secular. Whatever the interpretation of this rhetoric, it is clear that secularism is not a straightforward term. Moreover, the templemosque conflict in Ayodhya (and similar ones in Benares and Mathura) had been simmering for several decades. Only in the late 1980s did the movement to destroy the mosques and replace them with temples gain momentum. No doubt, something changed; there has been a rearrangement of the configuration that secularism and religious nationalism forms. However, many elements had been already present for quite a long time. It is a constantly negotiated arrangement that takes place primarily in the courts, but can be taken to the streets when a community, even a majority one, is made to feel that it is not fairly treated. ${ }^{24}$

The history of the partition of 1947, in which 12 million people were displaced, is a foundational trauma in Indian politics. Events in Gujarat in 2002 illustrate this perfectly. A train with Hindu activists returned from Ayodhya to Gujarat and partly burst into flames near the train station of Godhra. Narendra Modi, who was then the chief minister of Gujarat, declared without any evidence that the burning of the train was a pre-planned attack and that the Godhra incident was not a communal incident, but "a one-sided collective violent act of terrorism from one community." ${ }^{25}$ In his account of the pogrom in Gujarat in 2002, Parvis Ghassem-Fachandi argued that Modi deliberately made the incident into an act of terrorism against the Hindu nation by a minority that did not belong and had allegiance only to the enemy state of Pakistan. ${ }^{26}$ Ghassem-Fachandi points to three elements of signification that licensed widespread participation and consent in the killing of Muslims. First, a rumour was spread that Muslims had abducted Hindu women out of the train. Gujarati newspapers carried the story without any fact-checking. Some of them made it into a story about Hindu girls having been taken as sacrifices by Muslim ghosts. Second, the language of Hindu sacrifice, a language of offering into fire (homa or oblation), was applied. Third, the newspapers made excessive use of the photography of brutalized women and children, which, in GhassemFachandi's interpretation, was received with a mix of attraction and disgust. ${ }^{27}$ All of this created an atmosphere in which a Hindu majority was implicitly accepting the pogrom against Muslims without necessarily having directly participated in it. That silent majority has since carried Modi to electoral success.

When authorities turn a blind eye towards violence against a religious minority, the conditions for religious freedom are severely threatened. More generally, besides direct violence, Muslims have become second-rate citizens in India. The Sachar Report (http://www.minorityaffairs.gov.in/reports/sachar-committee-report (accessed 9 April 2020)), presented by Judge Sachar to the Indian Parliament in 2006, detailed the widespread discrimination against Muslims in India, but Indian governments have done little to nothing to change this. ${ }^{28}$

A significant element in the persecution of Muslims in India is the widespread assumption that Hinduism is the natural religion of the inhabitants of India while Muslims are denaturalized Hindus who have been converted by the sword to Islam. There is a general

\footnotetext{
${ }^{24}$ Chatterjee (2006).

${ }^{25}$ Ghassem-Fachandi (2012), p. 59.

${ }^{26}$ Ibid.

${ }^{27} \mathrm{Ibid}$.

${ }^{28}$ Sachar Committee Report.
} 
distrust of missionization and religious conversion that is shared by both moderate nationalists, like the followers of Mahatma Gandhi, and the radical nationalists like the members of the BJP. Conversion is seen as a violent act that has to be countered by both legislation and counter-violence. In short, propagation of the faith is not seen as a minority right. When Amartya Sen received the Nobel Prize for Economics in 1998, Ashok Singhal, the then president of the Vishwa Hindu Parishad (All-Hindu Assembly), commented that awarding this Nobel Prize to Sen was a Christian conspiracy against the nation and that Sen's developmental strategy to promote literacy was connected to Christian missionary efforts to proselytize under the cover of education. The VHP is an off-shoot of the paramilitary RSS and is closely allied with the BJP. Sen's Nobel Prize as well as that of Mother Theresa for her work for India's poor were both, in his view, attempts to undermine the Hindu nation. For the Hindu nationalists, Christian schools are covers for religious conversion.

Although India's Constitution allows the propagation of religion, it is generally felt by Hindus that Hinduism has grown from the soil, while Christianity and Islam come from outside and are foreign to it. They exist in India only because of proselytization among the native Hindu population. According to this view, conversion happened by the sword in the case of Islam and by material inducement under Christian colonialism. In other words, Christians and Muslims are in fact Hindus who have a false consciousness. In 1977, the Indian Supreme Court ruled that the right to propagate did not necessarily include a right to convert. It held that it was forbidden to convert minors and that adult Hindus wishing to convert had to provide the civil authorities with an affidavit. ${ }^{29}$

Notably, the upsurge of radical Hindu nationalism in the 1980s began with the highly publicized conversions of untouchable communities in and around the village of Meenakshipuram in South India to Islam in 1981. The secularist government of Indira Gandhi warned against the disuniting of India when "Gulf money" would induce untouchables and tribal peoples to leave the Hindu fold. One can see here already the slippage between "national unity" and "Hindu fold" by a self-avowed "secular" government. The Hindu nationalists went a step further in 1983 by organizing a revivalist campaign called the Ekatmata Yajna (Sacrifice for Unity), lasting over a month and consisting of processions, rituals, and rallies all over India and Nepal. This was followed in 1984 by the campaign to remove mosques from places where there had allegedly been Hindu temples before. The anxiety about conversion and the politics of numbers connected to it was and continues to be one of the prime sources of Hindu nationalist mobilization.

This anxiety does not only concern Muslim conversion, although the growth of the Muslim population is always the greatest worry, but also Christian conversion. In one grisly incident, the Australian missionary Graham Staines and his two minor sons were burnt to death by a mob from the Hindu Bajrang Dal (a youth wing of the VHP). One of the leaders of that mob was later sentenced to death, but this sentence was commuted to life imprisonment by the Odisha High Court-a judgment that was upheld by the Supreme Court. In its verdict, a bench of Mr Justice P. Sathasivam and Mr Justice B. S. Chauhan expressed its opinion as follows:

In the case on hand, though Graham Staines and his two minor sons were burnt to death while they were sleeping inside a station wagon at Manoharpur, the intention was to teach a lesson to Graham Staines about his religious activities, namely, converting poor tribals to Christianity.

${ }^{29}$ Rev Stanislaus v. Madhya Pradesh, 1977 Supreme Court Ruling (2) 611. 
They went on to add:

It is undisputed that there is no justification for interfering in someone's belief by way of "use of force", provocation, conversion, incitement or upon a flawed premise that one religion is better than the other. It strikes at the very root of the orderly society, which the founding fathers of our Constitution dreamt of. ${ }^{30}$

This led to an uproar in the liberal (English-language) newspapers. In a rare move, the Supreme Court later expunged the remarks from the verdict. The opinions in the Supreme Court, however, still reflect clearly how natural the anti-conversion sentiment seems even to the Indian judiciary. It is striking that explicit anti-conversion laws are enforced in Jharkand, Arunachal Pradesh, Odisha, Madhya Pradesh, Chhattisgarh, Gujarat, and Himachal Pradesh, all of which have sizeable tribal populations that are deemed particularly vulnerable for conversion to Christianity. On the other hand, conversion of tribals and untouchables to Hinduism is an explicit strategy of Hindu nationalists. They, however, do not find any juridical obstacles on their way. This shows how much the idea that Hinduism is the national civilization of India has come to be common sense in a juridical and political sense. Islam and Christianity are for the same reason not part of the "nation" or "national civilization."

\section{China: a comparative case}

It is not simply the nature of the electoral process that impels cynical politicians to mobilize people against minorities. Underlying is a deeper conceptualization of national civilization that makes such mobilization possible in the first place. To demonstrate this, it is useful to make a brief comparative excursion to a non-democratic society like China that does not have elections. In many ways, China's and India's nation-forms are comparable. Both are based on huge societies with deeply rooted cultural histories that have united large numbers of people over vast territories and over long periods. Both have adopted the nation form as a result of interaction with Western imperialism. Both nations share common ideas about progress, rationality, equality, and anti-imperialism, but the location of religion in Indian and Chinese nationalist imaginings is almost opposite. In general, religion is a valued aspect of Indian nationalism, whereas it is seen as an obstacle in Chinese nationalism. ${ }^{31}$ since the end of the nineteenth century, there has been an endless series of campaigns against religious superstition, against wasteful rituals, and against religious healing, all of which amount to a state-led campaign to modernize China by getting rid of popular religions. After the founding of the People's Republic in 1949, the communists destroyed the various redemptive societies (portrayed as feudal secret societies), which they saw as a threat to their power, but declared that official religions (Buddhism, Islam, Catholicism, Protestantism, and Daoism) needed to be protected under the principle of religious freedom. These religions were nationally organized as patriotic associations under the control of the state bureau of Religious Affairs and the Party's United Front Department.

Article 36 of the Chinese Constitution declares:

Citizens of the People's Republic of China enjoy freedom of religious belief. No state organ, public organization or individual may compel citizens to believe in, or not to believe in, any religion; nor may they discriminate against citizens who believe in, or do not believe in, any religion. The state protects normal religious activities. No one may make use of religion to engage in activities that disrupt public order, impair the

\footnotetext{
30 The Hindu (2011).

${ }^{31}$ Van der Veer (2014).
} 
health of citizens or interfere with the educational system of the state. Religious bodies and religious affairs are not subject to any foreign domination.

As is the case in India, this article gives the modernizing state full authority to intervene in questions of public order, public health, and public education. The post-colonial anxiety about foreign domination is also expressed clearly.

During its various campaigns against tradition culminating in the Cultural Revolution, the Communist Party employed its state power to marginalize religion and persecute religious specialists. This persecution still continues in Tibet and Xinjiang today. ${ }^{32}$ In the 1980s, these attacks on religion abated in the rest of China and more freedom was given for religious expressions, but always under the surveillance and arbitrary power of the state. Despite some very recent attempts to bridge the conflict between the Vatican and the Chinese state, these relations remain very tense..$^{33}$ Protestant activities are given more space and Protestantism grows in China, but, at any moment, a church building could be razed, often with the official "justification" that there has been a transgression of zoning and building laws.

The Chinese share with the Indians a deep distrust of Christian missionaries. Missionary activities have generally been prohibited in China, following Mao's famous statement in 1949 that American imperialism worked through spiritual aggression. ${ }^{34}$ Long before Mao, there was already a long Chinese tradition of suspicion of Christian missionaries as potential threats to state authority. From 1724, Catholicism was banned in China. It was the Opium Wars in the mid-nineteenth century that opened China up for missionary activities again. From this historical background, it is understandable that, as in India, there is in China a strong anti-Christian sentiment that connects Christian proselytization to imperialism.

After 2000, the Communist Party in China began to allow the furthering of Confucianism, Buddhism, and Daoism, as part of a revitalization of national civilizational heritage. ${ }^{35}$ Exempt from this shift from communist atheism to civilizational nationalism have been Christianity and Islam. Especially, the minority rights and freedom of religious expression of Muslims in China are severely threatened. Aspects of these anti-Muslim campaigns in China are comparable to the plight of Muslims in China. On the other hand, there are substantial differences. Muslims are a sizeable minority of 205 million in India, which is around $14.2 \%$ of the population. If one tries to imagine what the situation in India would be without the partition, Indian Muslims would constitute around a third of the Indian population. In China, on the other hand, Muslims are a relatively small minority of 19 million, or around $1.5 \%$ of the population. Moreover, they are divided into a number of ethnicities, of which the Hui (Chinese-speaking Han Muslims), the Kazakhs, and the Uyghur are the largest. Nevertheless, there is also a process of minoritization of Muslims underway in China. Most striking is the repression of Muslim Uyghur in Xinjiang-a situation that resembles the plight of Muslims in Indian Kashmir.

The Chinese authorities have treated the different Muslim ethnicities like all other minorities, following Stalin's nationalities policy in creating well-defined territories with clear ethnic autonomy. ${ }^{36}$ However, this has ended with growing separatism in Xinjiang on the Chinese Western frontier. Xinjiang is crucial to the Chinese state for its mineral wealth in terms of gas, oil, and coal, but also because of its location as the gateway to Central Asia, where even more mineral wealth might be tapped. To control Xinjiang, the area has been flooded with Han immigrants, induced by the state, which has changed the demography to

\footnotetext{
${ }^{32}$ Hillman \& Tuttle (2016).

${ }^{33}$ Madsen (2018).

${ }^{34}$ Mao (1961).

${ }^{35} \mathrm{Ji}$, Fischer, \& Laliberte (2019).

${ }^{36}$ Gladney (2004).
} 
the extent that the Han are now the majority. The resistance by the Uyghur population to this immigration is interpreted by the Chinese authorities as Islamic extremism.

China's Xinjiang resembles India's Kashmir in the sense that both areas are at the margins of the nation-state and inhabited by Muslim populations that are not fully integrated into the national story of civilizational unity. Although ethnicity and regional identity are the dominant elements in the response to state power, Islam does play a role in establishing ideas of martyrdom, holy war, and connections with Muslim insurgency elsewhere. In these regions, there are connections with transnational militancy, connecting Chechen, Afghanistan, Pakistan, Kashmir, and Xinjiang. Like global trading networks, they have a flexibility that allows them access to resources and opportunities that are difficult to control on the part of singular nation-states. This is especially the case for the cult of martyrdom, mainly inspired by Shi'a traditions, but easily appropriated for national and transnational causes, which connects them to global Islamic discourse. ${ }^{37}$

Much of this militancy has hardly anything to do with the Muslim populations that live outside of these conflict-ridden regions, but the currently pervasive language of "national security" makes it such that they are often suspected by central authority as being ideologically (religiously) connected. Nevertheless, Muslims have also suffered from the extreme secularist attacks by the Maoist state against their religious institutions, especially during the Cultural Revolution, when Buddhist, Daoist, and Muslim shrines were destroyed. ${ }^{38}$ What we see in China is very similar to what we see in India: a process of ethnic identification with a religion that is intimately tied up with state policies and the political process. Many Hui Muslims were hardly conversant with Islam and had blended in almost seamlessly with their non-Muslim neighbours except for some culinary peculiarities, such as their special noodles. In contrast to those in India, Muslims in China did not have to confront the construction of a majority religion through the political process, but instead they had to relate to the construction of an ethnic majority: the Han. ${ }^{39}$

However, after a number of spectacular terrorist attacks by Uyghur separatists in Kunming, Beijing, and Urumqi beginning in 2014, the Chinese authorities decided to stamp out Islamic extremism. In doing so, they have not been able to make a clear distinction between Islam and Islamism. As a result, Xinjiang has become a police state with extreme surveillance and police intervention in the private sphere. ${ }^{40}$ The latest reports on Xinjiang show that up to a million Muslims are being held in prison camps for "re-education" that includes long days of marching, singing patriotic songs, and memorizing Chinese laws. The Chinese government seems adamant about the destruction of the cultural and religious traditions of Xinjiang. The extent to which this anti-Muslim policy is spreading to other regions and to Hui Muslims is not yet clear. On the basis of personal observations in Yunnan (south-west China) in the summer of 2019, one can report the flourishing of the Muslim community in the Dali region as well as the removal of halal signs and Arabic signs around the main mosque of Kunming, the provincial capital. The larger picture is still unclear.

\section{Conclusion}

In India and China, religious freedom is severely restricted despite what is said about it in their Constitutions. In India, there has been a process of the nationalization of religion that has resulted in political antagonism between Hindus and Muslims. The first result of this process was the partition of 1947, which was accompanied by ethno-religious cleansing in

\footnotetext{
37 Tavakoli-Targhi (2002).

${ }^{38}$ Goossaert \& Palmer (2011).

${ }^{39}$ Gladney (1996).

${ }^{40}$ Zenz (2019).
} 
Pakistan and India. A considerable number of Muslims, however, stayed on in India. From the 1980s onwards, their situation has gradually deteriorated to the extent that they cannot count on the state protection of life and property. Both Muslims and Christians have been forced to cope with severe restrictions for religious propagation while Hindus have not felt such restrictions. A combination of fear of "foreign" monetary and fundamentalist influence (funding from Saudi Arabia and the Gulf), the idea that Muslims and Christians do not really belong to the nation but are beholden to foreign powers, and what has been called "the minority complex of a majority" has made religious conversion into a highly emotional and political issue.

Majoritarian mobilization in parliamentary democracies can crystallize around religious antagonism. However, majoritarianism can also be found in non-democratic, communist systems like that of China. In both cases, a civilizational nationalism that selectively includes and excludes groups in society is a danger to the principle of religious freedom. Therefore, democratic elections are not the core problem, but nationalism is.

Muslims are the quintessential strangers in India and China. They are in many ways excluded from civilization, civility, and civil society. Assimilation into the mainstream society does not always work, as demonstrated by the assimilation of German Jews into Bildungsbürger before the Holocaust. In India, one may be totally assimilated as a Muslim but, in times of communal violence, the ultimate check is whether one is circumcised or not. The body marks who one really, truly is. In China, Muslims are excluded from civilization and, to an extent, from important forms of civility, while the question of civil society does not come up in a communist society. In China, the real political problem emerges when the authorities think that the sovereignty of the state is challenged in Xinjiang. Philosophers like Seyla Benhabib suggest that the problem of the stranger can be solved in a legal manner by inclusive citizenship rights, but Muslims in India and China are citizens. ${ }^{41}$ It is the application of the concept of civilization as the foundation of the nation that excludes groups in society and makes them into strangers who are at the nation's mercy. Ultimately, this may even affect their citizenship. The recent introduction of the Citizenship Amendment Act 2019 (CAA) offered all undocumented migrants from Pakistan, Bangladesh, and Afghanistan access to Indian citizenship, provided they are not Muslims. ${ }^{42}$ The attempt to distinguish between different types of aspiring citizens, specifically Hindus versus Muslims, goes back to the partition but, in its new form, it will extend beyond refugees and migrants to the entire population. This will be helped by the introduction of a National Register of Indian Citizens (NRIC). It is likely that Muslims will be subjected to more frequent demands for proving citizenship and to higher standards of documentary evidence.

\section{References}

Bauman, Zygmunt (1989) Modernity and the Holocaust, Ithaca, NY: Cornell University Press.

Benhabib, Seyla (2004) The Rights of Others, Cambridge: Cambridge University Press.

Bhatt, Chetan (2006) "Democracy and Hindu Nationalism," in J. Anderson, ed., Religion, Democracy and Democratization, London: Routledge, 133-55.

Bilgrami, Akeel, ed. (2016) Beyond the Secular West, New York: Columbia University Press.

Brass, Paul R. (2003) The Production of Hindu-Muslim Violence in India, Seattle: Washington University Press.

Chatterjee, Partha (1998) "Secularism and Tolerance," in R. Bhargava, ed., Secularism and Its Critics, New Delhi: Oxford University Press, 345-79.

Chatterjee, Partha (2006) The Politics of the Governed, New York: Columbia University Press.

Das, Veena (1985) “Anthropological Knowledge and Collective Violence: The Riots in Delhi, November 1984." 1 Anthropology Today 4-6.

\footnotetext{
${ }^{41}$ Benhabib (2004).

${ }^{42}$ Citizenship Amendment Act (2019).
} 
The Economic Times (2018) "Women of All Ages Can Enter Sabarimala Temple, Rules Supreme Court," https:// economictimes.indiatimes.com/news/politics-and-nation/supreme-court-allows-women-to-enter-sabarimalatemple/articleshow/65989807.cms (accessed 11 September 2019).

Galanter, Marc (1998) "Secularism, East and West," in R. Bhargava, ed., Secularism and Its Critics, New Delhi: Oxford University Press, 258.

Ghassem-Fachandi, Parvees (2012) Pogrom in Gujarat: Hindu Nationalism and Anti-Muslim Violence in India, Princeton: Princeton University Press.

Gladney, Dru (1996) Muslim Chinese: Ethnic Nationalism in the People's Republic, Cambridge: Harvard University Press.

Gladney, Dru (2004) Dislocating China: Muslims, Minorities, and Other Subaltern Subjects, Chicago: University of Chicago Press.

Goossaert, Vincent, \& Palmer David (2011) The Religious Question in Modern China, Chicago: Chicago University Press. Hillman, Ben, \& Tuttle Gray (2016) Ethnic Conflict and Protest in Tibet and Xinjiang, New York: Columbia University Press.

The Hindu (2011), “Expunge Remarks against Graham Staines," https://www.thehindu.com/todays-paper/tpnational/lsquoExpunge-remarks-against-Graham-Staines/article15530578.ece (accessed 8 August 2019).

Ji, Zhe, Gareth Fischer, \& Andre de Laliberte, eds. (2019) Buddhism after Mao, Manoa: University of Hawaii Press.

Kohli, Atul (1990) Democracy and Discontent: India's Growing Crisis of Governability, New York: Cambridge University Press.

Künkler, Mirjam, John Madeley, \& Shylashri Shankar, eds. (2018) A Secular Age Beyond the West, Cambridge: Cambridge University Press.

Kymlicka, Will (1996) Multicultural Citizenship: A Liberal Theory of Minority Rights, Oxford: Oxford University Press.

Madsen, Richard (2018) "The Third Globalization of Catholicism in Greater China," in K. Dean \& P. v. d. Veer, eds., The Secular in South, Southeast, and East Asia, New York: Palgrave McMillan Publishing, 107-35.

Mao, Zedong (1961) "Friendship or Aggression," in Seleceted Works of Mao Tse-Tung, vol. 4, Beijing: Foreign Languages Press, 447-50.

Motzkin, Gabriel, \& Fischer Yochr (2008) Religion and Democracy in Europe, Jerusalem: Van Leer Institute.

Noorani, A. G. (2004) The Muslims of India: A Documentary Record, Oxford: Oxford University Press.

Phillips, Tom (2014) “China on Course to Become ‘World's Most Christian Nation' within 15 Years,” http:// www.telegraph.co.uk/news/worldnews/asia/china/10776023/China-on-course-to-become-worlds-most-Christiannation-within-15-years.html (accessed 8 August 2019).

Rawls, John (1971) A Theory of Justice, Cambridge, MA: Harvard University Press.

Shachar, Ayelet (2001) Multicultural Jurisdictions: Cultural Differences and Women's Rights, Cambridge: Cambridge University Press.

Smith, Donald Eugene (1963) India as a Secular State, Princeton: Princeton University Press.

Tavakoli-Targhi, Mohammad (2002) "Frontline Mysticism and Eastern Spirituality," ISIM Newsletter, 38-40.

Taylor, Charles (2007) A Secular Age, Cambridge: Harvard University Press.

Taylor, Charles (2016) “Can Secularism Travel?” in A. Bilgrami, ed., Beyond the Secular West, New York: Columbia University Press, 14-5.

Van der Veer, Peter (1988) Gods on Earth: The Management of Religious Experience and Identity in a North Indian Pilgrimage Centre, London: The Athlone Press (LSE Monographs on Social Anthropology).

Van der Veer, Peter (1994) Religious Nationalism: Hindus and Muslims in India, Berkeley: University of California Press.

Van der Veer, Peter (2014) The Modern Spirit of Asia: The Spiritual and the Secular in China and India, Princeton: Princeton University Press.

Van der Veer, Peter, ed. (2015) Handbook of Religion and the Asian City, Berkeley: University of California Press. Van der Veer, Peter (2016), The Value of Comparison, Durham: Duke University Press.

Weber, Max (1975) "Science as Vocation," in H. H. Gerth \& C. W. Mills, trans., eds., From Max Weber: Essays in Sociology, New York: Oxford University Press, 139, 155.

Zenz, Adrian (2019) “'Wash Brains, Cleanse Hearts': Evidence from Chinese Government Documents about the Nature and Extent of Xinjiang's Extrajudicial Internment Campaign.” 7 Journal of Political Risk 1-20.

Cite this article: van der Veer, Peter (2021). Minority Rights and Hindu Nationalism in India. Asian Journal of Law and Society 8, 44-55. https://doi.org/10.1017/als.2020.51 